\title{
Career and Gender: Between Rivers and Paths
}

\author{
Clara Selva Olid \\ Autonomous University of Barcelona, Barcelona, Spain
}

\begin{abstract}
Women's professional trajectory has been an interesting and recurrent subject for the last few decades. There are a lot of studies carried out which deal with the differences in the professional trajectories of men and women, from different approaches and units of analysis and from the ratios or proportions in different situations to the experiences undergone during their careers. This research intends to analyze the story of the professional trajectory from the main protagonists' experiences. The author intends to proceed through a comparison between men and women's cases, from a longitudinal perspective since 1998 to 2010. The analysis is focused on the personal, social, and organization elements which allow or constrain the professional development concerning gender of the 12 years of trajectory which this study deals with. The results are shown through two great metaphors: the river and the path, which allow us to understand and realize how gender is linked and promulgated in the working field, as well as how subjectivity is committed and explains the world named "objective”.
\end{abstract}

Keywords: professional career, gender, women, men, story, longitudinal perspective

\section{Introduction}

Women's professional trajectory is unquestionably one of the most consolidated studies of the last few decades. The different studies deal with this subject from different points of view and axis of analysis; most of them stem from an objective characterization of the phenomenon in terms of ratio and proportion, which counter the presence of women with men's in different fields, sectors, and positions. As a counterpoint to these most objective approaches, there are others which offer new ways to study the phenomenon, which are valuable themselves through the experiences lived, decisions made, helps obtained, and an endless set of aspects linked to the protagonists' point of view.

In literature, the trajectory refers to the different stages which an individual has to go through after finishing his/her training in a specific profession or in the moment to start a labour activity, in professional terms, labour or economic-social (Vázquez, 2009). Thus, all through our life, we will undergo different trajectories _ educational, educational-working, working, occupational or professional. Each one, as is obvious, has its own distinguishable elements, such as the moment and the social environment where they occur, and with convergence points, such as the transition moments (Jiménez, 2009).

As some authors claimed (Selva, Tresserra, Pallarès, \& Sahagún, 2012), the stories of the professional trajectory told by the protagonists themselves let us know the roles performed by the agents, the physical places they have occupied, the part which the institutions they have been linked to have played, the jobs performed, and the use they have put to their income; with the aim to shape, with all the data, a specific sort

Clara Selva Olid, Ph.D., postdoctoral researcher, Department of Social Psychology, Faculty of Psychology, Autonomous University of Barcelona. 
of trajectory instead of another one (Buontempo, 2000). In this context, women's and men's trajectories, through their comparison-contrast, are a privileged scenery to analyze the visible differences, either perceived or told between genders. These trajectories are already described from a different view in the corpus: in terms of ideal worker and simplicity for men's trajectories, and of commitment, abilities, and family responsibilities for women's (Durbin \& Tomlinson, 2010). Furthermore, it is pointed out that men follow more lineal trajectories, characterized by focusing on a specific field and being promoted up to their organizational summit (Durbin \& Tomlinson, 2010; Halford, Savage, \& Witz, 1997; Selva, 2012); whereas women follow more complex trajectories, inseparable of the personal and professional lay which they are marked by. In addition, it must consider specific gender structures, more or less subtle, which still exist in the working field and its organization, such as working social segregation or salary discrimination (Selva et al., 2012). That is to say, cultural, structural, and action dimensions affect women's and men's working destinies differently (Evetts, 2000). In brief, gender mediates and characterizes the practices and actions which are given in our life context, and which allow professional development (Omair, 2010).

In the early 1990s, Lepine (1992) described some distinguishable patterns in the development of manager women in comparison with men. Some of the different trajectories covered were fast ones, lineal ones, lateral ones, descendant or ascendant ones, and static ones (Omair, 2010). Gersick and Kram (2002) found out that many women's trajectories were Zig-Zag and more characterized by taking advantage of the opportunities presented in the working path itself than by the actions they had performed. Other authors (Eagly \& Carli, 2007) described their trajectories to responsibility positions as a labyrinth, with hindrances and challenges, such as gender discrimination or stereotypes amongst others; and Powell and Mainiero (1992) as well as White (1995) studied how family responsibilities amongst other personal, social, and organizational factors have an effect on women's career aspirations and their results.

In the different studies revised, it is clear that women's career is multidirectional, not lineal (Selva, 2012), characterized by developing in a wide variety of contexts and life experiences (Omair, 2010). In this sense, some authors (Budhwar \& Baruch, 2003; Omair, 2010; Pringle \& Mallon, 2003) have supported Lepine's approach (1992), putting to test the possibility to establish an only model of professional development for women. In this context, the stories are a privileged tool to investigate professional trajectories, social experiences, and their protagonists' subjectivities all through time. From a first level of interpretation of the experience undergone (Taracena, 2002), that is to say, the agent herself as a narrator is in charge of recomposing, her memories, transitions, and transformations through her stories (Márquez, 2001).

The work presented here is aimed at analyzing professional careers from the point of view of the agents' own experiences as they speak about them; that is to say, in narrative terms. The study adopts a longitudinal view, starting in the late 1990s (Martínez \& Pallarès, 2000) and ending in 2010. The analysis is focused on key elements and conditions that enable or constrain the process of career advancement, whether they are individual, organizational, or social. This paper offers the outcomes of two case studies and the contrast between them, underlining the role of gender in the professional world.

\section{Method}

The methodology is qualitative because of the type of data which we deal with, the stories, and the way 
to proceed in the analysis as well as in the role which theory plays in the focus of the investigation. The perspective of analysis is focused on stories of life, through the last 12 years of the protagonists' professional trajectories.

\section{Sample}

The sample is composed by two agents, a woman and a man, chosen by the similarities which have been found in their careers. The woman has a mid-management position in the financial informatics field. Both have had their careers for more than 20 years; for the last 10 years they have worked in the same company, and their organizations have undergone similar changes, but each one with different interpretations. They hold a similar functional role, the same career expectations concerning traineeship and the perception of facing a "glass ceiling" in their current companies, which prevents them from reaching management positions.

\section{Procedure}

Each participant went through two interviews, the first in 1998 and the second in 2010. The script for the second interview was designed in order to explore issues discussed during the first interview. In both cases, the first and second interviews lasted an average of 40 minutes. Interviews were recorded and transcribed verbatim. The content analysis was used as a support and the programmer Atlas.ti, version 5.1 (Muñoz, 2003).

\section{Data Analysis}

The analytic procedure is focused on what participants referred to as main incidents during the 12 years of professional career covered by the study. The units of analysis are the "events"-or those specific and outstanding facts, foreseen or to foresee, which can entail or explain a transition or a non-transition, in the agent's own trajectory; and the "periods" - or those facts or events prolonged in time, which are therefore monotonous. The interviews were read according to the events and periods, and their combinations, which shape both professional careers. Finally, the different components of the events and periods were identified; that is to say, the lived experiences, explanations, and strategies around each incident, as well as their conditions and consequences. This procedure made it possible to describe kinds of events, which subsumed particular events and periods in wide categories on the basis of common features. These great categories were defined and analyzed later on, and made it possible to find out the link between the different categories and related events as far as gender is concerned. All through the process of analysis, all the elements, either in an implicit or explicit way, were concerned with gender, as gender determining or aspects linked to space reconciliation were studied.

\section{Results}

Results are displayed in the form of an analytic table (see Table 1) (extracted from Selva, Pallarès, Sahagún, \& Tresserra, 2011), which unfolds the categories developed through the coding process - context, participants' roles, outstanding relationships, experience/feelings, attributions, expectations, and strategies, as well as two contrasting images that highlight the main features of both professional careers (a path for the male participant and a river for the female one) from the point of view of the participants themselves. Events and periods are shown in ranges of five years time, allowing a parallel reading of two paths. 
Table 1

Comparison-Contrast of the Categories of Analysis by Gender

\begin{tabular}{|c|c|c|c|c|c|c|c|c|}
\hline Participant & $\begin{array}{c}\text { Time periods } \\
\text { associated } \\
\text { with events }\end{array}$ & Context & $\begin{array}{c}\text { Participants' } \\
\text { roles }\end{array}$ & $\begin{array}{l}\text { Outstanding } \\
\text { relationships }\end{array}$ & Experience/ feelings & Attributions & Expectations & Strategies \\
\hline Q & \multirow[t]{2}{*}{-1998} & \multirow{6}{*}{\begin{tabular}{|c|} 
Growing \\
business. \\
Good time \\
for the sector, \\
market \\
expansion. \\
Co- \\
development \\
person- \\
organization.
\end{tabular}} & $\begin{array}{l}\text { Project } \\
\text { Manager }\end{array}$ & $\begin{array}{l}\text { Promoted by a } \\
\text { mentor }\end{array}$ & \multirow{2}{*}{$\begin{array}{l}\text { "I go to..." "I do..." Feeling of being } \\
\text { associated with the job. }\end{array}$} & \multirow{6}{*}{$\begin{array}{c}\text { Self- } \\
\text { confidence. } \\
\text { Ability, } \\
\text { preparation and } \\
\text { trust, "believing } \\
\text { in yourself" } \\
\text { Sufficient } \\
\text { preparation and } \\
\text { experience: "I } \\
\text { have always } \\
\text { been treated } \\
\text { well" "I had no } \\
\text { problem. " } \\
\text { Male company: } \\
\text { "Land of men " } \\
\text { Luck, "was in } \\
\text { the right place } \\
\text { at the right time } \\
\text { " }\end{array}$} & $\begin{array}{c}\text { Growth based on accountability } \\
\text { and achievement of objectives } \\
\text { "Meeting goals, targets...", "I want } \\
\text { to do "; "ambition". }\end{array}$ & $\begin{array}{l}\text { Control and decision- } \\
\text { making "planning ", } \\
\text { "involvement. " }\end{array}$ \\
\hline Q & & & Team leader & $\begin{array}{l}\text { Promoted by a } \\
\text { mentor }\end{array}$ & & & $\begin{array}{c}\begin{array}{c}\text { Growth based on the demonstration } \\
\text { of her capabilities "to prove my } \\
\text { worth", "the opportunity will } \\
\text { come". }\end{array} \\
\end{array}$ & $\begin{array}{l}\text { Order and } \\
\text { organization "control } \\
\text { of things". }\end{array}$ \\
\hline$\sigma^{\prime \prime}$ & \multirow[b]{2}{*}{ 1998-2003 } & & Team leader & $\begin{array}{l}\text { Beginning of } \\
\text { action for the } \\
\text { promotion }\end{array}$ & Decide generates feelings of well being. & & \multirow{4}{*}{$\begin{array}{c}\text { क } \\
\text { "To grow, learn" Visualizing } \\
\text { growth opportunities "continue to } \\
\text { grow in the organization" }\end{array}$} & Planning \\
\hline Q & & & Supervisor & $\begin{array}{l}\text { Promoted by a } \\
\text { mentor }\end{array}$ & $\begin{array}{l}\text { "Sense of sish out of water" "Will be all } \\
\text { right?" "What am I doing here?" }\end{array}$ & & & $\begin{array}{l}\text { Continuous } \\
\text { adaptation "I accepted } \\
\text { the demand of the } \\
\text { manager". }\end{array}$ \\
\hline$\sigma^{\prime \prime}$ & \multirow[b]{2}{*}{ 2004-2009 } & & \begin{tabular}{|c|} 
Team and \\
Project leader
\end{tabular} & $\begin{array}{l}\text { Promoted by a } \\
\text { mentor }\end{array}$ & $\begin{array}{c}\text { To decide generates feelings of well- } \\
\text { being. }\end{array}$ & & & Planning \\
\hline q & & & $\begin{array}{c}\text { Process } \\
\text { supervisor of } \\
\text { improvement } \\
\text { and } \\
\text { production }\end{array}$ & $\begin{array}{c}\text { Promoted by a } \\
\text { mentor }\end{array}$ & $\begin{array}{l}\text { "I've always been good", "I decided", "I } \\
\text { have no regrets". She doubts the success } \\
\text { in her choice of prioritizing the } \\
\text { professional life, in this temporary range. }\end{array}$ & & & $\begin{array}{l}\text { Prioritization of } \\
\text { personal and family } \\
\quad \text { life }\end{array}$ \\
\hline \multirow[t]{2}{*}{$\sigma^{\prime}$} & \multirow[t]{2}{*}{$2010-$} & \multirow{2}{*}{$\begin{array}{l}\text { Participants } \\
\text { organizational } \\
\text { units are } \\
\text { externalized. }\end{array}$} & Cross-role & $\begin{array}{l}\text { Unilateral } \\
\text { business } \\
\text { decision }\end{array}$ & $\begin{array}{l}\text { Loss of control and decision-making, } \\
\text { "strange situation", "hard process, } \\
\text { organization invisible", "I am going to } \\
\text { work for obligation", everyone looks for } \\
\text { him. }\end{array}$ & $\begin{array}{l}\text { Outsourcing of } \\
\text { computer } \\
\text { service. }\end{array}$ & $\begin{array}{l}\text { Regain control and decision- } \\
\text { making: "success","kkeep growing } \\
\text { wide.". Search personal and } \\
\text { professional balance. }\end{array}$ & $\begin{array}{c}\text { Waiting. } \\
\text { Impossibility of } \\
\text { planning. "Common } \\
\text { sense" "to conform to } \\
\text { the situation". } \\
\end{array}$ \\
\hline & & & $\begin{array}{c}\text { Production } \\
\text { manager }\end{array}$ & $\begin{array}{l}\text { Promoted by a } \\
\text { mentor }\end{array}$ & $\begin{array}{l}\text { "Doing different things," "my goal is a } \\
\text { change"," new business, another way of } \\
\text { doing things, another culture " }\end{array}$ & $\begin{array}{c}\text { Holistic } \\
\text { knowledge of the } \\
\text { organization. }\end{array}$ & $\begin{array}{l}\text { Learn. Search personal and } \\
\text { professional balance. }\end{array}$ & $\begin{array}{l}\text { Prioritize things, tasks } \\
\text { and spaces. }\end{array}$ \\
\hline
\end{tabular}

The interpretation of the different units of analysis in connection to the different events and periods involved brings to light the important role which gender has in the working field (Selva et al., 2012). In this context, women present constant features of their promotions to higher positions: (1) a marked attitude of waiting concerning future promotions, in spite of their wish to be promoted; (2) the fact of continuing working as an orientation which leads their professional development, on which they base their promotion expectations as well as their needs to show themselves as valuable; and (3) the story of their professional trajectory as a result of the external elements which have made it possible: mentors, luck, and waiting. These external elements tinge their progress and professional promotions with the most absolute lack of planning. Therefore, these are future elements which have to be waited for and are finally regarded as normal as she told "that is the way it is". This phenomenon is known as "hopeful disappointment" (Selva et al., 2012) or the paradox of trying not to expect what is already expected. Regarding compatibility, the woman claims not having had any problem, as she conceives her personal and professional space as an only sphere, in which her tasks, activities, and roles are flowing. In keeping with literature, woman's career is mainly characterized by horizontal promotions; the previously mentioned Zig-Zag paths, in which one needs more steps to reach the same place (Gersik \& Kram, 2002). As regards to man, his promotion is active, that is to say, he carries out action principles to fulfill his professional expectations. He has an internal control of the different events and periods, and he plans them. His professional expectations are based on his own and his company's 
growth, and he assumes his professional success and progress. In brief, the story of his professional development is the result of his actions and strategy principles (Sterret, 1999; Super, 1963). Whereas for men being well prepared is the key factor to be promoted, women, in addition to education, need a mentor. Both the man's and the woman's stories show that professional space lies in the first place of the priorities set until there is a professional stability. When this moment comes, they give priority to their personal life and family space rather than to the professional one, when they have descendants or second descendants children.

\section{Conclusions}

The stories of both agents, she and he, give us some knowledge about their personal and professional reality. They bring us closer to the experience of their trajectories and the elements which characterize them, their perception about it and the strategies they have carried out to achieve their professional expectations (Evetts, 2000). The results of the study show that the stories of the professional trajectories of the agents in the study lead us to imagine two visual metaphors: a river in the case of the female agent and a rural path for the male one (Selva et al., 2012). The river is the result of the different transitions which the woman undergoes all through her career. They are mainly reactive, that is to say, proposed by mentors or by the organization itself, which she accepts adapting herself to the situations and organizing her spaces. It was as if a waiting for opportunities or changes in the water currents which she has to follow. The rural path, characteristic of the male agent, reflects an active way, dug by his own actions — on which he has to walk and take up a set of actions to reach his objective and where he has to avoid hindrances and stones which he may come across, with the aim of achieving his goal or getting to the end of the path.

Both images of river career and path career are more than a way of synthesizing participants' accounts about their own professional careers. It is not just a matter of subjectivity, but subjectivity engaged in a world of taken for granted prescriptions and proscriptions which are differentially applied for women and men. Speaking of women's career in terms of a river in which "you have to go with the flow" and men's career in terms of "a hard, winding, rural path" has more to do with how gender and work are intertwined and enacted and how subjectivity is always engaged with the so-called "objective world", and not only a matter of personality or individual differences (Selva et al., 2011).

To sum up, these metaphors show us how gender is socially and culturally constructed, and how it has specific flairs, attitudes, and social roles ascribed, depending on the biological sex. Gender explains specific ways to read and interpret the agents' personal and professional role, in relation to the others as well as themselves. Thus, the results of this study bring us closer to see how the differences in acting, perception, and working performance between men and women are produced and reproduced. Moreover, it shows how they solve the rules which tinge the professional field, either they are more subtle or less, and which act and perpetuate the differences between genders.

At this point, it will be interesting for future investigations to cast our eyes over the professional trajectory told by women and men, allowing making the careers presented as a river or as a rural path more or less extending, as well as turning the most subjective reality into the most objective one. At the same time, it will be interesting to see what factors and determinants shape or make the different careers possible, and what perception and strategy principles the female agents develop as regards to their trajectories. 


\section{References}

Budhwar, P., \& Baruch, Y. (2003). Career management practices in India: An empirical study. International Journal of Manpower, 24(6), 699-719.

Buontempo, M. P. (2000). Job placement of graduates: A study from the career paths. Corrientes, Argentina: Northeastern University.

Durbin, S., \& Tomlinson, J. (2010). Female part-time managers: Networks and career mobility. Work Employment Society, 24(4), 621-640.

Eagly, A., \& Carli, L. (2007). Women and the labyrinth of leadership. Harvard Business Review, 85(9), 63-71.

Evetts, J. (2000). Analysing change in women's careers: Culture, structure and action dimensions. Gender, Work and Organisation, 7(1), 57-67.

Felmlee, D. (1984). The dynamics of women's job mobility. Work and Occupations, 11, 259-281.

Fernández, N. (2002). The professional development of workers as a competitive advantage for companies. Journal of Management, 2(1), 65-90.

Gersick, C., \& Kram, K. (2002). High achieving women at midlife: An exploratory study. Journal of Management Inquiry, 11(2), 104-127.

Halford, S., Savage, M., \& Witz, A. (1997). Gender, careers and organisations. London: Macmillan.

Jiménez, M. (2009). Trends and findings in studies of history: A methodological approach for classifying workforce development. Electronic Journal of Educational Research, 11, 1-21.

Lepine, I. (1992). Making their way in the organization: Women managers in Quebec. Women in Management Review, 7(3), 17-21.

Márquez, F. (2001). Career living and working in poor subjects. Propositions, 32, 226-240.

Martínez, M., \& Pallarès, S. (2000). Women in positions of responsibility: From middle management to senior management. Barcelona: Catalan Women's Institute.

Muñoz, J. (2003). Qualitative analysis of textual data with ATLAS / ti 5. Barcelona: Autonomous University of Barcelona.

Omair, K. (2010). Typology of career development for Arab women managers in the United Arab Emirates. Career Development International, 15(2), 121-143.

Powell, G., \& Mainiero, L. (1992). Cross-currents in the river of time: Conceptualizing the complexities of women's careers. Journal of Management, 18(2), 215-237.

Pringle, J., \& Mallon, M. (2003). Challenges for the boundaryless career odyssey. International Journal of Human Resource Management, 14(5), 839-53.

Selva, C. (2012). Explaining his own career: A longitudinal perspective on gender, organizations and personal life in the stories of careers. (Thesis, University of Barcelona)

Selva, C., Pallarès, S., Sahagún, M. A., \& Tresserra, O. (2011). Career and gender: Two case studies and its comparison. 12th European Congress of Psychology (ECP), Istambul.

Selva, C., Tresserra, O., Pallarès, S., \& Sahagún, M. A. (2012). The river and the career path as: Contrasting stories with gender. Quaderns of Psychology, 14(1).

Sterrett, E. (1999). A comparison of women's and men's career transitions. Journal of Career Development, 25(4), 249-259.

Super, D. (1963). Career development: Self-concept theory. New York: College Entrance Examination Board.

Taracena, E. (2002). The construction of the narrative of involvement in career paths. American Profiles, 21, 117-141.

Vázquez, M. (2009). Trends and findings in studies of history: A methodological approach for classifying workforce development. Electronic Journal of Educational Research, 11(1), 1-21.

White, B. (1995). The career development of successful women. Women in Management Review, 10(3), 4-15. 